УДК 621.311

DOI https://doi.org/10.32838/2663-5941/2019.3-1/07

Kyryk V.V.

National Technical University of Ukraine

"Igor Sikorsky Kyiv Polytechnic Institute"

\title{
GENETIC METHOD FOR OPTIMAL RECONFIGURATION OF THE POWER DISTRIBUTION NETWORKS
}

The paper presents the general statement and innovative solution to tackle the important present-day applied problem of developing new methods for optimal configurations of high voltage distribution networks. Reconfiguration of the power distribution network considered under normal operation mode is developed by using the genetic algorithm, which enables the determination of an optimal network configuration so that power losses over transmission lines are minimized, the standard quality of electric power is provided, and the appropriate voltage at consumers' connection points is assured. Moreover, this approach allows operation economy due to minimum connectivity of electrical network circuit design, and minimal outage losses.

Key words: high voltage distribution network, reconfiguration, genetic algorithm, functional circuit design reconfiguration.

Introduction. The problem of reliable and qualitative electric power supply in $6-35 \mathrm{kV}$ power distribution networks can be solved by providing the optimal control of power flows, and adjusting the parameters of regulation and compensation devices. At the present age of intellectual technologies, the solution to this problem requires developing smart electrical power networks, as stated within the scoIpe of implementation of Smart Grid concept. Smart grid concept acquires special importance when dealing with the operation mode control problems in $6-35 \mathrm{kV}$ power distribution networks, characterized by underlevel of dispatching control centralization. Moreover, the problem of intellectualization of distribution network control is complicated by large dimensions of the system, low system observability, and a restricted range of technical arrangements available for adaptive control.

In operating power distribution networks there is often a problem of topology change, or that of reconfiguration of functional circuit design, intended to minimize electrical power network maintenance expenses and to ensure the appropriate power quality supply $[1$, c. $35 ; 4$, c. 12$]$.

In fact, each of the possible functional circuit designs is characterized by a range of parameters, such as the reliability of electric power supply, the power quality at consumer's connection points, and the power losses over transmission lines. Thus, it is of great importance to consider the optimization problem for functional circuit design configuration of power distribution networks.

Formulation of the problem. It should be mentioned that in order to find the solution to the problem of optimal configuration of power distribution networks scientists today usually make use of the estimation models based on the comparison of several alternatives of electrical power network configuration. In most of the cases, the electrical power network reconfiguration is carried out by one criterion, and with imposing some restrictions. Classical optimization models and methods have not been widely used because of the complexity of the problem, which is caused by the following aspects $[2$, c. $86 ; 3$, c. 10 ; 5, c. 174]:

- the problem of electrical power network configuration optimization is of multi-criteria, so that the problem solution should consider the requirements of operation economy (profitability), electrical power supply reliability, power quality, environmental friendliness etc. under the condition of little accuracy of explicit network state;

- optimization methods of power distribution network configuration should take into account the dynamical character of electrical supply system development;

- optimization function of electrical power network configuration is discrete and contains discontinuities;

- the information about electrical system parameters is of probabilistic or even uncertain nature.

The purpose of the present research is to develop the method of optimal reconfiguration of functional circuit design in the power distribution network on the basis of genetic algorithm.

The solution of the problem. The problem of finding the optimal functional circuit design reconfiguration of power distribution network can be solved 
as a target criterion function. It allows designing the optimal configuration of electrical power network simultaneously by four criteria, namely minimum connectivity of the circuit design, voltage deviation, economic component of outage losses, and active power losses:

$$
F=k_{1} \sum_{i=1}^{N} K_{i}+k_{2} \sum_{i=1}^{M}\left|\delta U_{i}\right|+k_{3} \sum_{i=1}^{M} \alpha_{i} P_{i} Y_{i}+k_{4} \sum_{i=1}^{L} \Delta P_{i} \rightarrow \min
$$

where $k_{1}, k_{2}, k_{3}, k_{4}-$ are the weight coefficients intended for joining incommensurable parameters as part of the target criterion function; $K_{i}$ - is alarm coefficient, which is equal to unity in case the contacts of $i$-th switch apparatus are closed, and to null if the contacts of $i$-th switch apparatus are open; $N$ - is the total number of the switch apparatus, which determines the configuration of the functional circuit design of the electrical power network; $\delta U_{i}-$ is the deviation of operating voltage of $i$-th circuit point beyond the permissible limit; $M$ - if the total number of branch points in the circuit design; $\alpha_{i}-$ is the level of load limitation of $i$-th point of the functional circuit design in case of emergency perturbation; $P_{i}-$ is the active power of $i$-th point load in the circuit design; $Y_{i}-$ is the specific economic losses caused by limitation of $i$-th point load in the circuit design; $\Delta P_{i}-$ is active power losses on $i$-th section of the functional circuit design of the power distribution network; $L-$ is the total number of sections in the functional circuit design under consideration.

It is obvious that in expression (1) the first component of the optimization function provides the minimal connectivity of the functional circuit design in the power distribution network; the second component represents the power quality at the points of consumer's voltage connection; the third component stands for the reliability of electrical supply, that is the economic component of outage losses; and the fourth components is the operation economy (profitability) of the system's operating mode with power losses in the network.

In determining the numerical values of weight coefficients it is recommended to reduce all four components of the target criterion function to one order, for example to unity, and to consider their mutual influence. For that reason, it is possible to adopt the following correlation for the installed power of the network $P_{s}$ :

$$
\left\{\begin{array}{l}
k_{1}=1 / N ; \\
k_{2}=1 / M ; \\
k_{3}=\frac{1}{P_{s} Y}=\frac{1}{(3,5 \ldots 4) P_{s}} ; \\
k_{4}=\frac{1}{P_{s}}
\end{array}\right.
$$

The proposed optimization function of the functional circuit design configuration of power distribution network is a complex nonlinear discrete function of many variables, the form of which restricts the use of traditional methods of optimization, in particular the methods of nonlinear programming, such as Lagrangian multiplier method and gradient descent method. Thus, following from the target criterion function proposed, the genetic algorithm has been used to determine the optimal functional circuit design configuration of power distribution network.

The key idea of the approach proposed here is to identify the characteristics and properties of the possible solutions of distribution network configuration by means of binary code and vector, which contains binary chains of the properties of alternative solutions. It is obvious that to a certain degree the vector matches the simplified mathematical model of a biological organism genotype, containing the full information about this organism. This allows us to apply the basic genetic operations of cross breeding, which will lead to the formation of new solutions with new properties.

Therefore, it is possible to present the functional circuit design configuration of the electrical power network under consideration by means of the binary chain, each bit of which contains the information on the state of a matching section of the circuit design (" 0 " - if the section is the open connector and is not a part of load cover section of the consumers connected; and "1" - if the section is in process). The overall search space consists of $2 \mathrm{n}$ possible states, where $n-$ is the total number of circuit design sections of the electrical power network.

Since the electrical power network may contain hundreds and thousands of sections, the problem solutions of optimal network configuration becomes very complicated. For the purpose of accelerating the operation, increasing the efficiency of genetic algorithms, and decreasing the probability of incoherent circuit design of the electrical network, we suggest restricting the search space by zone allocation of unconditional attractors of power supplies, which contain the sections of the circuit design that provide power supply of certain consumers at any combinations of permissible operation mode parameters (e.g. voltage at power supply bus-bars, load power etc.). This part of the circuit design stays unvaried, and can be neglected in the reconfiguration. The other part of the circuit design represents a "boundary" zone, where the search for places to locate reserve connectors for the purpose of optimum sectionalisation of power distribution network is directly done. 
Allocation of unconditional attractor zones of power supply and "boundary" zones within the circuit design of the power distribution network allows greatly reducing the search space of optimal solution. This increases the efficiency of applying mathematical apparatus of genetic algorithms to the solution of optimization problem without additional time-consuming control of connectivity conditions of functional network diagram.

Hence, in the optimal reconfiguration of power distribution network we determine only the boundary zone with a restricted number of sections on which the breaker can be switched on or off. Boundary zone sections make up a binary chain for the genetic algorithm. Graphical interpretation of boundary zone is presented in Fig. 1.

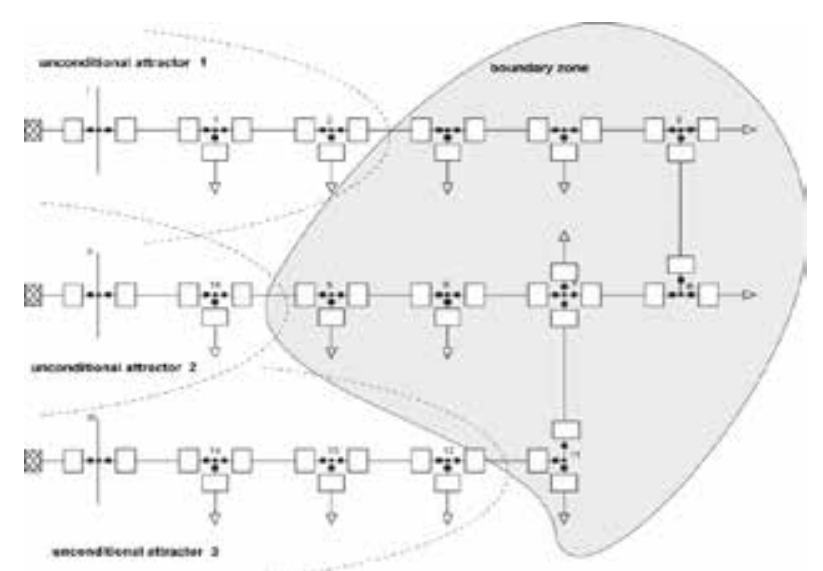

Fig.1. Graphical interpretation of a boundary zone of the electrical network

The developed method [6, c. 58] of optimal power distribution network reconfiguration based on using the genetic algorithms consists in applying the following procedures:

1. All power supplies of power distribution network are considered in succession and in pairs, and unconditional attractor zones of each power source are identified on the basis of the minimax approach. For this purpose, the power of distribution substation loads of one power supply is maximized and the power of other power supply is minimized. Further, the circuit design section to which the electric centre of load belongs is determined by the following expression:

$$
l_{x}=\frac{\sum_{i=1}^{N} P_{i} l_{0 i}}{\sum_{i=1}^{N} P_{i}},
$$

where $N$ - is the total number of sections of a double-fed line; $l_{i}-$ is the length of $i$ - th section of the circuit design; $P_{i}-$ is the active power of load at the end of $i$ th section; $l_{0 i}$-is the distance from the beginning to the end of $i$-th line section.

Conditional excluded sections between electric centres of load divides the circuit design into two incoherent parts, and each incoherent part determines the unconditional attractor zone of a current power supply. These operations are also carried out for other power sources. The parts of the circuit design that are not within the area of any unconditional attractor make up a boundary zone (Fig. 1), in which the search for places to locate the reserve connectors will be done.

2. The method of coding the genetic information about power distribution network configuration is applied. For this purpose, the binary chain is formed, whose length is equal to the number of sections within a boundary zone. Each bit of the chain determines the condition of a corresponding section of the circuit design (" 1 " - the section is in process, " 0 " - the section is a reserve connector section).

3. The initial population of possible configuration solutions of circuit designs of the power distribution network is created. The volume of initial population depends on the dimensions of a boundary zone of the circuit design, and constitutes 20-30 individuals. A phenotype of all configurations of circuit designs, or of individuals of initial population, is developed. One of the configurations should match the initial circuit design of the distribution network. Other phenotypes are filled by means of the random-number generator with uniform distribution.

4. For all individuals of the initial population of possible functional circuit design configurations the values of target criterion function (1) is calculated, which determines the optimality degree of the corresponding network configuration solution. Also, the average value of the target criterion function for initial population as a whole is determined.

5. A roulette wheel for determining the current parent pair of circuit design configurations of power distribution network is created by the calculation method. For this purpose, the wheel is divided into sectors, and the number of sectors equals the number of individuals of the current population. The lower the values of the target criterion function for the corresponding configuration solution, the larger the width of sector. The width of each sector is determined in relative units by the expressions:

$$
F_{i}^{\prime}=\frac{1}{F_{i}} ; \quad \Delta_{i}=\frac{F_{i}^{\prime}}{\sum_{i=1}^{N} F_{i}^{\prime}},
$$

where $F_{i}$ - is the value of target criterion function for the circuit design of the current population; $i-$ is 
the index of the current circuit design (individual) within the population; $N$ - is the total number of circuit designs within the population; $\Delta_{i}-$ is the width of "roulette" sector which matches $i$-th circuit design of population in relative units.

6 . The roulette wheel is started twice by means of the random-number generator with uniform distribution, and two individuals of the current population whose genetic material will be used for the formation of a new daughter design are determined.

7. The genetic operator of two-point crossover is applied to the selected parent pair, and the result will be a new daughter solution.

8. By means of the random-number generator with uniform distribution it is determined whether it is necessary to apply the genetic mutation operator to the generated new phenotype, and this operator is applied in case of necessity.

9. For a new configuration solution, the value of target criterion function of optimality is calculated by expression (1).

10. The roulette wheel is formed to determine the current population individual that will be replaced by the generated new solution. In this case, the width of wheel sectors should be larger with higher values of the target criterion function of a corresponding phenotype. This width is calculated in relative units by expression:

$$
\Delta_{i}=\frac{F_{i}}{\sum_{i=1}^{N} F_{i}} .
$$

As a result, the width of each roulette sector is directly proportional to the value of target criterion function for the corresponding configuration solution. One-time start of the roulette wheel is done by means of the random-number generator with uniform distribution to determine the individual of the current population that will be replaced by a new daughter configuration solution. The replacement and computation of the average value of criterion function is performed for the updated population of circuit designs.

11. The conditions of genetic algorithm convergence are verified. If the number of generations of the generated daughter solutions has attained the limit value, or all phenotypes of the current population of possible configurations of the functional circuit design have resulted into one solution, the work of genetic algorithm is finished, and the best configuration of the circuit design of the current population with the minimum value of criterion function is accepted as the optimum solution. Otherwise, the following cycle of genetic algorithm is carried out, starting from procedure 5 .
Results and discussion. The developed method of determining the optimal circuit design reconfiguration of the power distribution network by using the genetic algorithm has been tested on a subsystem of the electrical power network formed by feeders 4 and 18 of "Gnivan" substation, feeder 20 of "Gnivan" substation, and feeder 22 of "CFD" substation (Fig. 2).

Non-selected part of the circuit design with $52 \mathrm{sec}-$ tions represents a boundary zone. The condition of connectors of this zone in the genetic algorithm is represented as a binary chain of 52 bit, for example, as "FFFEFFDFFFF7F".

The initial population of a boundary zone of the genetic algorithm consists of 20 circuit designs, one of which is a configuration of the functional circuit design at the current position of reserve connectors, and genotypes of all others are filled by means of the random-number generator. The operation of genetic algorithm is illustrated in the diagram in Fig. 3. Here, curve $F_{\text {min }}(g)$ represents the time history of the value of target criterion function of optimality in generations for the best design solution; $F_{\text {mid }}(g)$ - is the time history of average value of criterion function for the whole generation.

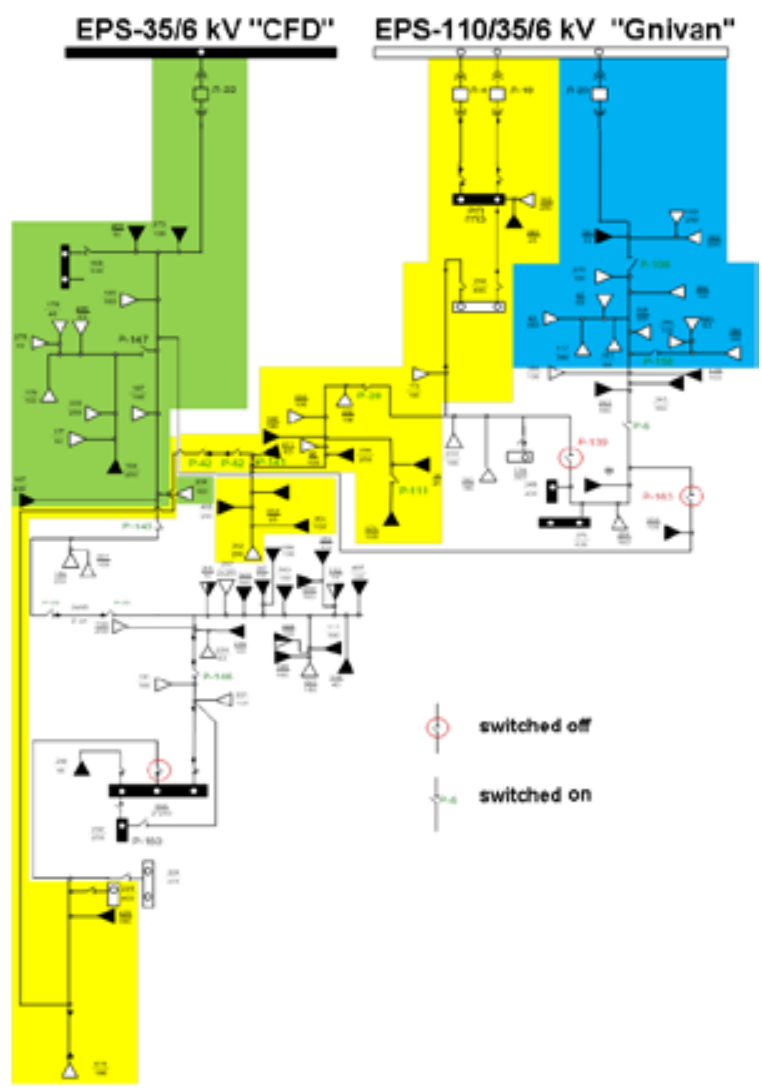

Fig. 2. The distribution network with selected unconditional attractors of feeders and a boundary zone 
As seen from Fig, 3, the value of the criterion function for the best individual practically does not change after 30 full cycles of genetic algorithm are complete, which demonstrates that convergence of search process has been achieved. The optimal boundary zone of the functional circuit design under consideration is presented in the diagram in Fig. 4.

Conclusion. The efficiency of the method proposed for optimal reconfiguration of the power distribution network has been proved by the practical application of genetic algorithm for optimisation of power distribution networks configuration. The example of this method described in this paper shows that the optimal

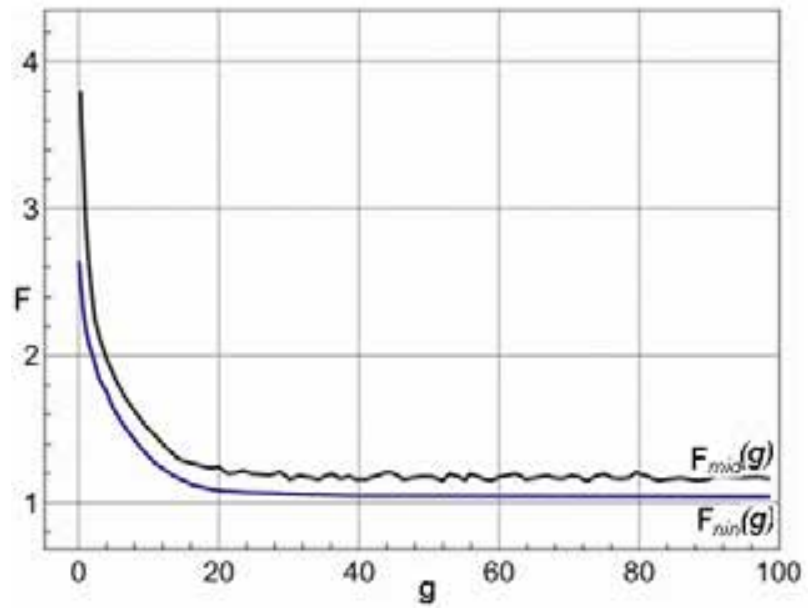

Fig. 3. Values of criterion function in generations reconfiguration of power distribution network enables decreasing active power net losses by approximately $10 \%$ (from $0.19 \mathrm{MW}$ to $0.17 \mathrm{MW}$ ), and ensures the appropriate quality and reliability of the power supply. During the algorithm implementation about 600 alternatives of configurations were considered on the boundary zone, which represents less than $0.01 \%$ of the general search space required for a complete circuit design of power distribution network.

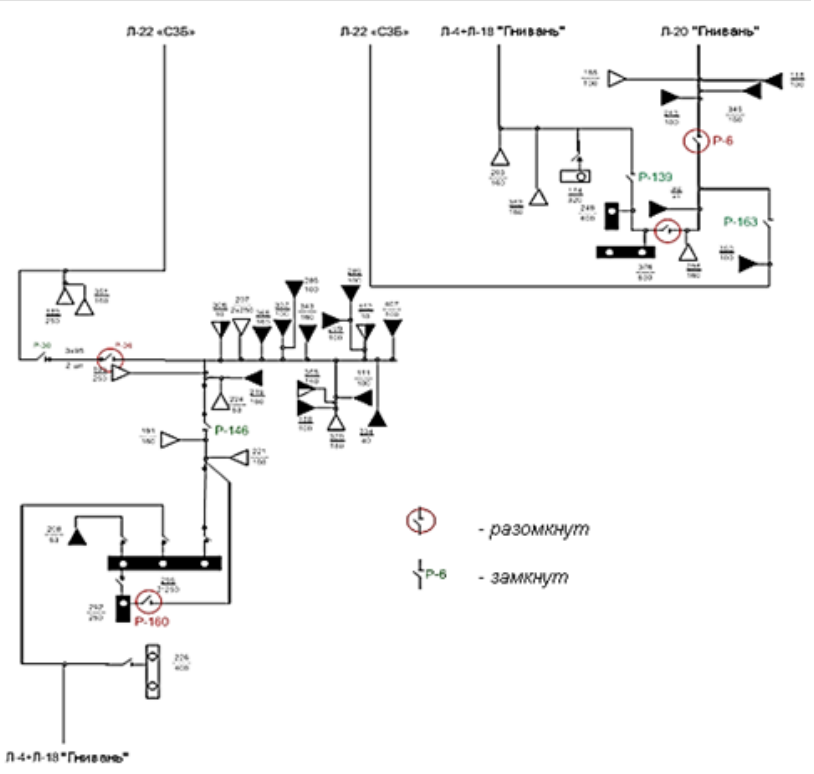

Fig. 4. An optimal boundary zone of the functional circuit design of the thirtieth generation

\section{REFERENCES:}

1. Arzamastsev D.A. Models and methods of optimization and development of grids / D.A. Arzamastsev, A.V. Lypes, A.L. Myzyn. Sverdlovsk: UPY, 1976. 148 s. (in Russian)

2. Economy and optimization of the modes of grids: inter-university collection of scientific works / otv. red. V. M. Cheban. - Novosybyrsk: Yzd-vo NETY, 1984. - 159 s. (in Russian)

3. Gay O.V., Tugai Yu.I. The optimal points of sectionalization in distributive networks. Pratsi Instytutu elektrodynamiky Natsionalnoi Akademii Nauk Ukrainy. 2011. Iss. 28/ Pp/ 10-14. (in Ukrainian)

4. Kothari D.P. Power system optimization / D. P. Kothari, J. S. Dhillon. New Deli, Prentice-Hall of India, 2007. $572 \mathrm{p}$.

5. Kumar K. FDR Particle Swarm Algorithm For Network Reconfiguration Of Distribution Systems / K. Kumar, N. Ramana, S. Kamakshaiah. Journal of Theoretical and Applied Information Technology. 2012. Vol. 36. №2. P.174-180.

6. Kyryk V. An increase of energy efficiency of distributive networks is with the use of SMART-technologies / B.V. Tsyhanenko, D.M. Sumskyi, V.V. Kyryk, T.L. Katsadze. Elektronika i zviazok.2016. №4(93). T. 21. S. 58-63. (in Ukrainian)

\section{ГЕНЕТИЧНИЙ МЕТОД ДЛЯ ОПТИМАЛЬНОЇ РЕКОНФІГУРАЦЇ̈ РОЗПОДІЛЬНОЇ ЕЛЕКТРИЧНОЇ МЕРЕЖІ}

У роботі представлені загальні положення та інновачійні рішення для вирішення важливої сучасної прикладної проблеми розробки нових методів оптимальної реконфігурації високовольтних розподільних мереж. Реконфігурачія розподільної електричної мережі розглянута в нормальному режимі ї̈ роботи з використанням генетичного алгоритму, який дозволяє визначити оптимальну конфігурацію мережі так, щоб втрати потужності по лініях електропередавання були мініммальними, забезпечува- 
лася стандартна якість електроенергії та відповідна напруга в пункті підключення споживачів. Крім того, ией підхід забезпечує мінімальну зв'язаність схеми мережі та мінімальні економічні втрати.

Ключові слова: високовольтні електричні мережі, реконфігурація, генетичний алгоритм, иільова функиія реконфігураиії схеми

\section{ГЕНЕТИЧЕСКИЙ МЕТОД ДЛЯ ОПТИМАЛЬНОЙ РЕКОНФИГУРАЦИИ РАСПРЕДЕЛИТЕЛЬНОЙ ЭЛЕКТРИЧЕСКОЙ СЕТИ}

В работе представлены общие положения и инновачионные предложения для решения важной современной прикладной проблемы разработки новых методов оптимальной реконфигурации высоковольтных распределительных сетей. Реконфигурация распределительной электрической сети рассматривается в нормальном режиме ее работы с использованием генетического алгоритма, который позволяет определить оптимальную конфигурацию сети так, чтобы потери мощности по линиям электропередачи были минимальными, обеспечивалось стандартное качество электроэнергии и соответствующее напряжение в пункте подключения потребителей. Кроме этого, подход обеспечивает минимальную связанность схемы электрической сети и минимальные экономические потери.

Ключевые слова: высоковольтные электрические сети, реконфигурация, генетический алгоритм, иелевая функиия реконфигурации схемы. 